\title{
Assigning stranded bottlenose dolphins to source stocks using stable isotope ratios following the Deepwater Horizon oil spill
}

\author{
A. A. Hohn ${ }^{1, *}$, L. Thomas ${ }^{2}$, R. H. Carmichael ${ }^{3,4}$, J. Litz $^{5}$, C. Clemons-Chevis ${ }^{6}$, \\ S. F. Shippee ${ }^{7}$, C. Sinclair ${ }^{8}$, S. Smith ${ }^{9,12}$, T. R. Speakman ${ }^{10}$, M. C. Tumlin ${ }^{11}$, E. S. Zolman ${ }^{10}$ \\ ${ }^{1}$ National Oceanic and Atmospheric Administration, National Marine Fisheries Service, Southeast Fisheries Science Center, \\ 101 Pivers Island Rd., Beaufort, NC 28516, USA \\ ${ }^{2}$ Centre for Research into Ecological and Environmental Modelling (CREEM), University of St Andrews, The Observatory, \\ Buchanan Gardens, KY16 9LZ, UK \\ ${ }^{3}$ Dauphin Island Sea Lab, Dauphin Island, AL 36528, USA \\ ${ }^{4}$ University of South Alabama, Mobile, AL 36688, USA \\ ${ }^{5}$ National Oceanic and Atmospheric Administration, National Marine Fisheries Service, Southeast Fisheries Science Center, \\ 75 Virginia Key Dr., Miami, FL 33149, USA \\ ${ }^{6}$ Institute for Marine Mammal Studies, PO Box 207, Gulfport, MS 39502, USA \\ ${ }^{7}$ Marine Wildlife Response, 1557 Highway 98 West, Mary Esther, FL 32569, USA \\ ${ }^{8}$ National Oceanic and Atmospheric Administration, National Marine Fisheries Service, Southeast Fisheries Science Center, \\ Mississippi Laboratories, 3209 Frederic St., Pascagoula, MS 39567, USA \\ ${ }^{9}$ Audubon Aquarium of the Americas, 1 Canal Street, New Orleans, LA 70124, USA \\ ${ }^{10}$ National Oceanic and Atmospheric Administration, National Ocean Service, National Centers for Coastal Ocean Science, \\ Hollings Marine Laboratory, 331 Fort Johnson, Charleston, SC 29412, USA \\ ${ }^{11}$ Louisiana Department of Wildlife and Fisheries, 2000 Quail Drive, Baton Rouge, LA, 70898, USA \\ ${ }^{12}$ Present address: Amazon River Dolphin Conservation Foundation, 805 Hidalgo Street, New Orleans, LA 70124, USA
}

\begin{abstract}
The potential for stranded dolphins to serve as a tool for monitoring free-ranging populations would be enhanced if their stocks of origin were known. We used stable isotopes of carbon, nitrogen, and sulfur from skin to assign stranded bottlenose dolphins Tursiops truncatus to different habitats, as a proxy for stocks (demographically independent populations), following the Deepwater Horizon oil spill. Model results from biopsy samples collected from dolphins from known habitats $(\mathrm{n}=205)$ resulted in an $80.5 \%$ probability of correct assignment. These results were applied to data from stranded dolphins $(\mathrm{n}=217)$, resulting in predicted assignment probabilities of $0.473,0.172$, and 0.355 to Estuarine, Barrier Island (BI), and Coastal stocks, respectively. Differences were found west and east of the Mississippi River, with more Coastal dolphins stranding in western Louisiana and more Estuarine dolphins stranding in Mississippi. Within the Estuarine East Stock, 2 groups were identified, one predominantly associated with Mississippi and Alabama estuaries and another with western Florida. $\delta^{15} \mathrm{~N}$ values were higher in stranded samples for both Estuarine and BI stocks, potentially indicating nutritional stress. High probabilities of correct assignment of the biopsy samples indicate predictable variation in stable isotopes and fidelity to habitat. The power of $\delta^{34} \mathrm{~S}$ to discriminate habitats relative to salinity was essential. Stable isotopes may provide guidance regarding where additional testing is warranted to confirm demographic independence and aid in determining the source habitat of stranded dolphins, thus increasing the value of biological data collected from stranded individuals.
\end{abstract}

KEY WORDS: Carbon · Nitrogen · Sulfur $\cdot$ Tursiops truncatus $\cdot$ Stock structure $\cdot$ Gulf of Mexico

${ }^{*}$ Corresponding author: aleta.hohn@noaa.gov
() The authors and (outside the USA) the US government 2017. Open Access under Creative Commons by Attribution Licence. Use, distribution and reproduction are unrestricted. Authors and original publication must be credited. 


\section{INTRODUCTION}

Information collected from stranded marine mammals can serve as a tool for monitoring free-ranging populations (Peltier et al. 2012). For example, the species composition of strandings may reflect the biodiversity of living populations in adjacent waters (Pyenson 2010, Byrd et al. 2014). The relative number or composition of strandings can be used to monitor long-term (Peltier et al. 2013) or cyclical (Evans et al. 2005, Peltier et al. 2014) shifts in distribution or anomalous strandings, such as unusual mortality events (UMEs; NMFS-OPR 2016), that indicate the presence of disease, high levels of fishery interactions, or other events or factors affecting the population (Byrd et al. 2008, Yang et al. 2008, Wilkin et al. 2012, Hohn et al. 2013, Litz et al. 2014). Samples from stranded marine mammals can be used to obtain data for estimating demographic parameters of species or populations for which data are otherwise difficult to obtain (Hohn et al. 1996, Lockyer \& Kinze 2003, Mattson et al. 2006, Schwacke et al. 2017, this Theme Section). In these ways, robust stranding programs have substantially contributed to our knowledge of marine mammal populations. One important issue for interpreting data from strandings is accounting for spatial and temporal variation in the probability of animals becoming stranded and then the stranding being reported (Peltier et al. 2014). While we do not deal with this question here, a second major issue in using strandings to reflect free-ranging populations, and the motivation for this paper, is that the source population for stranded marine mammals is often unknown.

The more complex the population structure, the more complex the challenge to identify source populations of stranded animals. Recent research has demonstrated that common bottlenose dolphins Tursiops truncatus (hereafter bottlenose dolphins or dolphins) exhibit extensive population structuring, meeting the definition, for management purposes, of stocks as demographically independent populations (Moore \& Merrick 2011). Along the US Atlantic coast, Rosel et al. (2009) identified at least 5 genetically differentiated coastal and estuarine populations, confirming demographic independence despite the absence of hard barriers, such as isolated estuaries. Genetic analyses, coupled with photo-identification (photo-ID) results, have identified structuring of bottlenose dolphin populations over relatively small coastal ranges such as for T. truncatus in Hawaii (Baird et al. 2009, Martien et al. 2012), Brazil (Fruet et al. 2014), South Africa (Natoli et al. 2005), Spain (Fernández et al. 2013), and the Mediterranean Sea (Gaspari et al. 2015), as well as for $T$. australis in southern Australia (CharltonRobb et al. 2015). Further, while estuaries are porous with regard to movements of dolphins, significant genetic differentiation has been shown to occur among bay, sound, or estuarine (BSE) stocks and between BSE and their adjacent coastal stocks (Sellas et al. 2005, Möller et al. 2007, Rosel et al. 2009). Genetics has additionally shown that structuring can occur on a finer scale, with more than 1 population within close proximity of one another within an estuary (Rosel et al. 2009, Mirimin et al. 2011, Ansmann et al. 2012, Richards et al. 2013, Fruet et al. 2014).

Bottlenose dolphins are the most abundant coastal cetaceans from the US mid-Atlantic states to Texas. Along the northern Gulf of Mexico (GoM) coast of the US, 36 stocks are recognized under the Marine Mammal Protection Act, 31 of which are defined as BSE stocks and 3 as coastal stocks (Vollmer \& Rosel 2013, Waring et al. 2015). Photo-ID and telemetry results support the concept of resident estuarine stocks of dolphins, from Florida (Wells \& Scott 1990, Fazioli et al. 2006, Balmer et al. 2008, Conn et al. 2011, BassosHull et al. 2013) through Mississippi (K. D. Mullin et al. unpubl. data) and Louisiana (Wells et al. 2017, this Theme Section) to Texas (Bräger et al. 1994, Irwin \& Würsig 2004). These long-term photo-ID studies are limited to relatively few areas, and are primarily conducted in and of greatest value for stocks inhabiting estuarine or other semi-enclosed areas. Genetic studies have not been conducted at most of the photo-ID sites to confirm demographic independence or whether genetic assignment to stock is possible.

The assessment of injury to bottlenose dolphins following the Deepwater Horizon (DWH) oil spill required estimating injury by stock, necessitating assignment of stranded dolphins to their source stock (DWH NRDAT 2016). From March 2010 to July 2014, much of the northern GoM experienced a UME (Carmichael et al. 2012a, Litz et al. 2014). While some mortalities occurred in the months prior to the spill, the largest and most prolonged increases in mortality occurred after the spill and were primarily attributed to the spill (Venn-Watson et al. 2015a,b, Colegrove et al. 2016, DWH NRDAT 2016). Prior to the DWH oil spill, few studies had been conducted on the stock structure of bottlenose dolphins in the coastal and estuarine areas that were most heavily oiled during the DWH event, from western Louisiana through the western Panhandle of Florida (Michel et al. 2013, DWH NRDAT 2016). The available studies, however, suggested site fidelity and independent estuarine stocks. Photo-ID surveys in the Mississippi Sound 
(from the mid-1980s) provided evidence for longterm estuarine residency with seasonal changes in abundance (Hubard et al. 2004). Results from a survey in Barataria and Caminada Bays, in southern Louisiana, indicated a small, closed population with some seasonal variation in sighting patterns (Miller 2003).

In the immediate aftermath of the DWH oil spill, photo-ID or genetics results available to identify the source stocks of stranded dolphins remained limited relative to the spatial extent of strandings. As a result, another method was needed to assign individual stranded dolphins to coastal or estuarine stocks. Stable isotopes have been used across a range of taxa as dietary tracers and spatial markers (Crawford et al. 2008, B. S. Graham et al. 2010, Newsome et al. 2010, Ben-David \& Flaherty 2012). In the marine environment, stable isotopes of carbon indicate linkages to initial sources of primary productivity (e.g. seagrass, salt marsh, phytoplankton; Michener \& Schell 1994, Currin et al. 1995), nitrogen reflects trophic level and the influence of different nutrient sources (Peterson \& Fry 1987, McClelland et al. 1997, Rossman et al. 2013), while sulfur can further distinguish marine from freshwater- or terrestrial-derived sources relative to variation in dominant microbial processes (Peterson \& Fry 1987, Connolly et al. 2004). The link between sulfur values and salinity has been well demonstrated in marine species, including along the northern GoM (Fry 2002, Fry \& Chumchal 2011, MacAvoy et al. 2015). Thus, different combinations of stable isotope composition correlate with variation in environmental conditions, providing a tool to define populations and track large-scale movement patterns associated with migratory or foraging behavior (Lee et al. 2005, Hobson et al. 2010, Fry \& Chumchal 2011).

In cetaceans, a number of studies found amonggroup differences in stable isotopes that were used to define stocks. The predominant elements used have been carbon and nitrogen (Witteveen et al. 2009, Ohizumi \& Miyazaki 2010, Fernández et al. 2011, Aurioles-Gamboa et al. 2013, Borrell et al. 2013, Giménez et al. 2013). For bottlenose dolphins along the GoM coast of Florida, mean stable isotope ratio values of carbon, nitrogen, and sulfur differed between estuarine and coastal and/or offshore groups, with sulfur isotope values increasing seaward (Barros et al. 2010). Other stable isotope studies in marine mammals have been coupled with independent indicators, such as contaminants, trace elements, or fatty acids, to define stock structure (Borrell et al. 2006, Wilson et al. 2012, Quérouil et al. 2013, Browning et al. 2014a, Ansmann et al. 2015). Hence, stable isotopes in tissues of stranded dolphins could provide an alternative approach to assign stranded dolphins to stocks, pending more direct measures of demographic independence.

The goal of the current study was to test whether stable isotopes of carbon, nitrogen, and sulfur could be used to assign dolphins stranded after and in areas most affected by the DWH oil spill to estuarine or coastal source habitats, as a proxy for stocks. Under the current National Marine Fisheries Service stock definitions (Waring et al. 2015), barrier island and estuarine animals are included as part of the BSE stock. Due to the growing body of evidence from telemetry (Wells et al. 2017, K. D. Mullin et al. unpubl. data) and genetics (Rosel et al. 2017, this Theme Section), indicating that dolphins from barrier islands form a distinct group, we treated animals from barrier islands as a potential stock. The approach for stock assignment was to first develop a model from samples collected from known source populations ('Estuarine,' 'Barrier Island,' and 'Coastal') via biopsy sampling and then to apply those model results to predict the stocks of origin for stranded animals.

\section{MATERIALS AND METHODS}

\section{Sample collection}

Stable isotope analysis was conducted on skin samples collected from live animals, via remote biopsy or during capture-release health assessments, or from stranded animals. Remote biopsy sampling occurred during vessel-based surveys in 2006 and from 2010 to 2013 using biopsy tips measuring $7 \times 25 \mathrm{~mm}$ or $10 \times$ $25 \mathrm{~mm}$ (Sinclair et al. 2015). Collection data, including location and date, were recorded for each biopsy sample on a 'Deepwater Horizon Oil Spill Response Biopsy Sheet' or a 'Marine Mammal Sighting Sheet' (see Appendices A and B in Sinclair et al. 2015). Biopsy samples were collected during health assessments in 2011 and 2013 following accepted capturerelease health-assessment protocols (Wells et al. 2004, Schwacke et al. 2014). Samples from stranded dolphins were collected from 2010 to 2013 following stranding-response protocols detailed by Litz et al. (2014). Skin collected via biopsy sampling included up to $25 \mathrm{~mm}$ depth of the epidermis and dermis; skin collected from strandings was influenced by state of decomposition but also included the full thickness of available epidermis and upper layers of dermis. For all samples, attached blubber was removed. 
Skin samples collected via biopsy sampling were placed in cryovials and stored in a liquid nitrogen vapor shipper in the field until transferred to an ultracold freezer for long-term storage at $-80^{\circ} \mathrm{C}$ (small vessels) or were placed directly in an ultracold freezer carried on larger vessels (Sinclair et al. 2015). Skin samples collected from stranded animals initially frozen at close to $-20^{\circ} \mathrm{C}$ were later transferred to $-80^{\circ} \mathrm{C}$. All samples remained frozen until stable isotope analysis.

Given the large number of strandings following the DWH oil spill (Litz et al. 2014, Venn-Watson et al. 2015b), a subset of available skin samples from stranded animals was selected for stable isotope analysis using several criteria: (1) the strandings occurred after the beginning of the DWH oil spill (on or after 20 April 2010), (2) the stranding occurred within the geographic range most affected by the DWH oil spill (Louisiana to the western Panhandle of Florida; Michel et al. 2013, DWH NRDAT 2016), (3) the total length of a stranded animal was $>170 \mathrm{~cm}$ to exclude perinatal and young of the year (Fernandez \& Hohn 1998) to avoid ontogenetic effects (Knoff et al. 2008, Riccialdelli et al. 2013), and (4) carcasses were fresh dead or exhibited only moderate decomposition (condition code $\leq 3$ [Smithsonian Institution Coding System] Geraci \& Lounsbury 2005) to reduce effects of decomposition, except for 11 carcasses of advanced decomposition (condition code 4) used to test for effects of decomposition.

\section{Sample preparation and stable isotope analysis}

Analysis of skin samples for stable isotope ratio composition was conducted by IsoForensics (Salt Lake City, UT; http://isoforensics.com/) in-house and at the Stable Isotope Ratio Facility for Environmental Research (SIRFER; http://sirfer.utah.edu). Samples were processed and analyzed as detailed by Valenzuela et al. (2012). In summary, skin samples were freeze-dried overnight or up to $24 \mathrm{~h}$ (FreeZone Freeze Dry System), lipid-extracted with a 2:1 chloroform:methanol mixture for $48 \mathrm{~h}$ using a Soxhlet extractor, and then cut into fragments. For analysis of carbon and nitrogen isotope ratios, $1.00 \mathrm{mg}( \pm 10 \%)$ of dried, delipified skin was weighed into tin capsules ( $3.5 \times 5 \mathrm{~mm}$, Costech Analytical); for analysis of sulfur isotope ratios, $2.00 \mathrm{mg}( \pm 10 \%)$ was weighed into tin capsules. Every 20th sample was analyzed in duplicate, except for 1 sample for which there was insufficient tissue and a different sample was analyzed in duplicate.
Carbon and nitrogen isotope ratio measurements were made at IsoForensics using a MAT 253 isotope ratio mass spectrometer (Thermo Finnigan) operated in continuous flow mode; tin capsules were loaded into an autosampler (Costech Analytical) interfaced with an elemental analyzer (EA; Thermo Finnigan) through a Conflo IV interface. Sulfur isotope ratio measurements were made at SIRFER using a Delta S isotope ratio mass spectrometer (Thermo Finnigan) operated in continuous flow. At SIRFER, tin capsules were loaded into a zero-blank autosampler (Costech Analytical) interfaced with an EA (Carlo Erba) through a Conflo III interface. In the EA, samples were flash combusted to produce $\mathrm{CO}_{2}, \mathrm{~N}_{2}$, and $\mathrm{SO}_{2}$ for carbon, nitrogen, and sulfur isotope analysis, respectively. Resultant gases were chromatographically separated and carried to the mass spectrometer via He stream.

The samples were analyzed alongside a series of laboratory reference materials. For each measurement, 2 of the reference materials (i.e. the 'normalization' reference materials) were used to (1) correct for potential memory, time ('drift'), and/or voltage effects and (2) normalize measured data to the international isotope scales. The other reference materials were used for quality control (QC) to verify corrections and normalization. Reference materials used for carbon and nitrogen stable isotope analysis included ground keratins that had been calibrated using the international isotope reference materials USGS40 and USGS41 to give reference values relative to VPDB of $\delta^{13} \mathrm{C}_{\mathrm{VPDB}}=-23.12 \%$ and $-11.9 \%$ and $\delta^{15} \mathrm{~N}_{\mathrm{AIR}}=$ $+1.38 \%$ and $+10.69 \%$ for normalization reference materials DS (dall sheep horn) and ORX (oryx antelope horn), respectively. Analytical precision, defined as the standard deviation of the QC reference material, powdered keratin (POW), was $+0.02 \%$ for $\mathrm{C}(\mathrm{n}=$ $\left.71, \delta^{13} \mathrm{C}_{\mathrm{VPDB}}=-24.03\right)$ and $+0.04 \%$ for $\mathrm{N}(\mathrm{n}=71$, $\delta^{15} \mathrm{~N}_{\text {AIR }}=+5.96 \%$ ). For sulfur stable isotope analysis, reference materials included a silver sulfide and zinc sulfide (normalization) and 2 ground keratins (QC). The normalization reference materials had been calibrated to the international isotope reference materials IAEA-S-1, -2 , and -3 to give reference values on the Vienna Canyon Diablo Troilite (VCDT) scale of $\delta^{34} \mathrm{~S}_{\mathrm{VCDT}}=+17.9 \%$ and $-31.9 \%$ for reference materials UU-S-1 and UU-S-2, respectively. Analytical precision was $0.3 \%$ based on replicate measurements of POW $\left(\mathrm{n}=50, \delta^{34} \mathrm{~S}_{\mathrm{VCDT}}=+4.2 \%\right)$ and ground eider duck down ( $\mathrm{n}=94, \delta^{34} \mathrm{~S}_{\mathrm{VCDT}}=+16.7 \%$ ).

Due to the short-term unavailability of the mass spectrometer at SIRFER, biopsy samples collected in coastal waters of Mississippi in 2006 were sent to the Center for Stable Isotope Biogeochemistry (CSIB) at 
the University of California, Berkeley, for sulfur isotope analysis. For the sulfur stable isotope analysis conducted at CSIB, POW was used as the reference material, and measured $\delta^{34} \mathrm{~S}$ values matched the long-term statistics on POW analyzed at SIRFER, which included all samples from coastal waters of Louisiana. There was no significant difference in the mean $\delta^{34} \mathrm{~S}$ values between the 2 sets of coastal samples $(\mathrm{n}=21$ from Louisiana and $\mathrm{n}=14$ from Mississippi, $t$-test, $\mathrm{p}=0.26$, mean $\delta^{34} \mathrm{~S}_{\mathrm{SIRFER}}=+14.96[ \pm 2.3$ $\mathrm{CI}]$, mean $\left.\delta^{34} \mathrm{~S}_{\mathrm{CSIB}}=+14.36[ \pm 2.8 \mathrm{CI}]\right)$.

Stable isotope values are reported in $\delta$-notation, reflecting the ratio of the heavy to light isotope relative to the standard material, using the following standard expression:

$$
\delta E \%=\left[R_{\text {sample }} / R_{\text {standard }}-1\right] \times 1000
$$

where $E$ is the isotope $\left({ }^{13} \mathrm{C},{ }^{15} \mathrm{~N},{ }^{34} \mathrm{~S}\right)$ and $R$ is the molar ratio of the heavier to lighter isotope for the sample and its corresponding standard, respectively. Comparative values of stable isotopes are expressed as higher or lower, heavier or lighter, and enriched or depleted, with respect to the relative value, in \%o, of the heavier isotope (Campbell et al. 2014). For example, $+15 \%$ is greater, more positive, more enriched than $+10 \%$.

\section{Data analysis}

\section{Training data}

A subset was selected from the full set of biopsy samples by choosing samples from geographically distinct locations that excluded areas of likely spatial overlap of stocks, creating a training subset of data. Given differences in the estuarine systems west and east of the Mississippi River Bird's Foot Delta (hereafter referred to as the MS River Delta), west and east sides were subsampled separately to create the training dataset. West of the MS River Delta (hereafter referred to as 'West'), the training dataset included samples collected (1) in the upper estuary of Barataria Bay (Estuarine), (2) near Grand Isle and Isle Grande Terre (Barrier Island [BI]), and (3) in coastal waters from $2 \mathrm{~km}$ off the beach to the $20 \mathrm{~m}$ isobath offshore of Barataria Bay (Coastal). East of the MS River Delta (hereafter referred to as 'East'), the training dataset included samples collected (1) near the mainland (upper estuary) in Mississippi and Chandeleur Sounds (Estuarine), (2) very near the barrier islands of Mississippi Sound, including Horn, Petit Bois, and Dauphin Islands (BI), and (3) in coastal waters offshore of BI (Coastal). Coastal animals from
West were assumed to belong to the Western Coastal Stock while those from East were assumed to belong to the Northern Coastal Stock (Waring et al. 2015).

\section{Stock assignment analysis}

To describe the relationship between stable isotopes and stocks, we conducted a recursive partition analysis (also called a classification and regression tree, CART; Sutton 2005), using the rpart library (version 4.1-9) in the statistical software R (version 3.1.3; Therneau \& Atkinson 2015). This analysis proceeded in 2 phases. First, a tree was built by splitting the data according to binary partitions of the candidate covariates. Candidate covariates included the factor variables region (East/West) and sex (male/female), and the continuous variables $\delta^{13} \mathrm{C}, \delta^{15} \mathrm{~N}$, and $\delta^{34} \mathrm{~S}$. Temporal variables (year and month/season) were also considered, but they were confounded with stock because the Coastal stock was only sampled in the summer and East Coastal samples were collected in a year when no Estuarine or BI samples were collected. Each split was on a single covariate, and was chosen to minimize the misclassification rate of observations or some estimator of the unknown population misclassification rate in each branch. Second, the tree was pruned by removing branches that contributed the least; this pruning was achieved by reference to a measure of model complexity. Our analysis closely followed the suggestions of Therneau \& Atkinson (2015) for tree building and pruning. In choosing splits, we used the Gini rule (Therneau \& Atkinson 2015), with a minimum of 5 observations per group and per terminal node (or leaf), and prior probabilities that were proportional to observed data frequencies with a 0/1 loss. In pruning branches, we used the complexity parameter, and chose the structure that minimized this quantity over 10-fold cross validation. Results from the CART analysis were applied to the stranding samples to assign those samples to stocks (Estuarine, BI, or Coastal). Summary statistics and comparison tests were performed using SAS software (version 9.4); following convention, the $\alpha$ level used for statistical significance was 0.05 .

\section{RESULTS}

\section{Training dataset}

In total, 335 biopsy samples were collected (Fig. 1, and see Table S1 in the Supplement at 

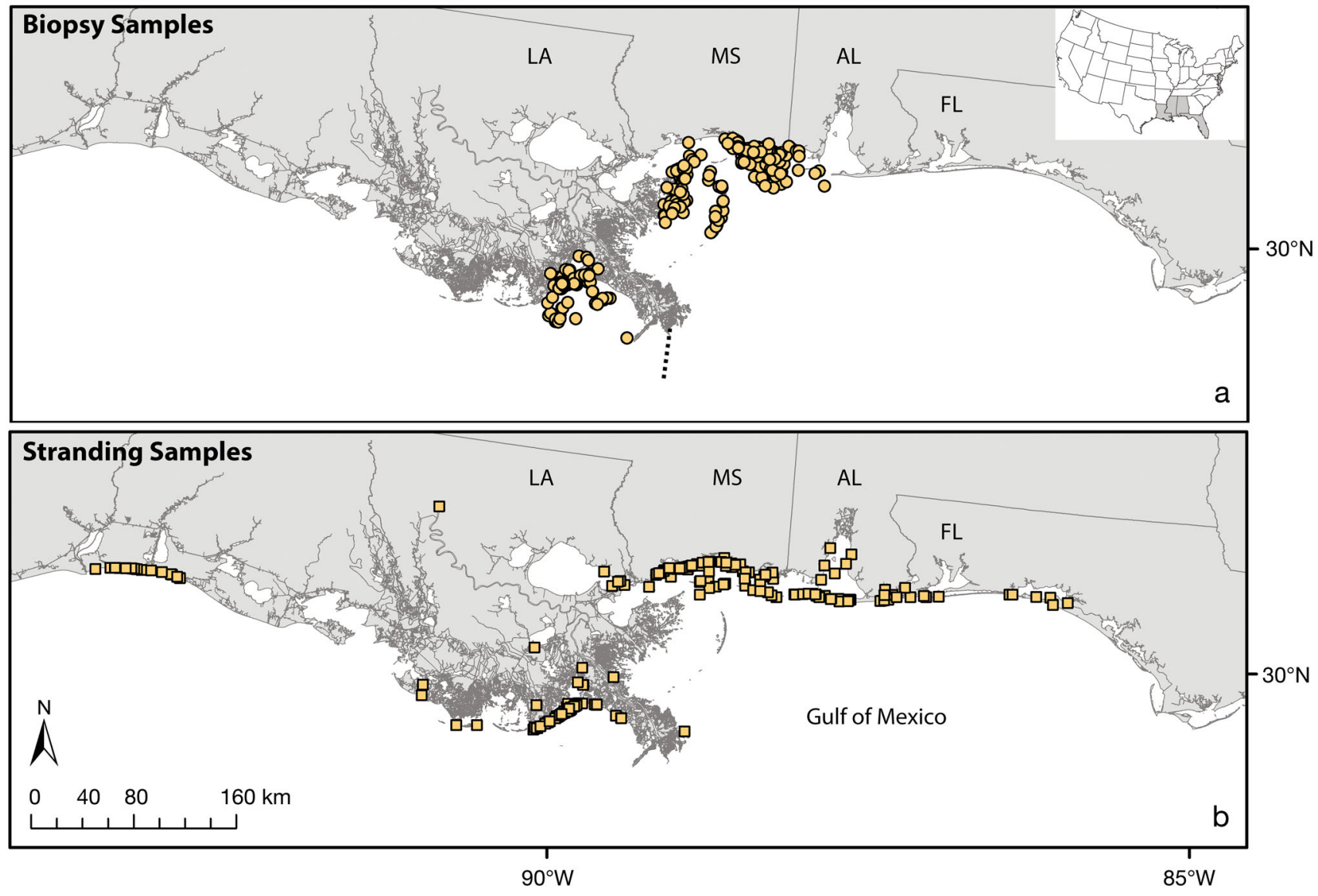

Fig. 1. Geographic distribution of (a) biopsy and (b) stranding samples of common bottlenose dolphins Tursiops truncatus analyzed for stable isotope ratios. In (a), the dashed line extending approximately southward from the tip of the Mississippi River Bird's Foot Delta indicates the demarcation between the Northern and Western Coastal Stocks (Vollmer \& Rosel 2013). The shaded states in the USA map inset were included in the current analysis. LA: Louisiana, MS: Mississippi, AL: Alabama, FL: Florida

www.int-res.com/articles/suppl/n033p235_supp.pdf), of which 205 were selected for inclusion in the training dataset (Table 1, Fig. 2). The correct classification rate from the training dataset was $80.5 \%$ from 5 partitions ( 6 terminal nodes: 1 Coastal, 2 BI, and 3 Estuarine) using the predictor variables $\delta^{34} \mathrm{~S}$, region, and $\delta^{13} \mathrm{C}$, respectively (Table 2, Fig. 3). To put this in context, the correct classification rate expected by chance from random assignment of animals to stock is 0.39 , and the probability of achieving an $80.5 \%$ or better correct classification by chance is $<1 \times 10^{-6}$. The correct classification rate at each terminal node provided an assignment probability for samples with characteristics corresponding to that node, e.g. 28 of the 38 animals within Coastal were sampled within the Coastal training stratum, so the estimated probability of being Coastal for animals in that node is $28 / 38$ or 0.736 (Fig. 3).
Mean stable isotope values across the 6 nodes ranged from -19.6 to $-16.8 \%$ for $\delta^{13} \mathrm{C}$ (overall range of -21.3 to -15.1 ), +13.8 to $15.9 \%$ for $\delta^{15} \mathrm{~N}$ (overall range of $12.0-17.0 \%$ ), and +10.8 to $15.6 \%$ for $\delta^{34} \mathrm{~S}$

Table 1. Sample sizes within each habitat or stock area for the training dataset derived from the full set of biopsy samples of common bottlenose dolphins Tursiops truncatus

\begin{tabular}{|llrcr|}
\hline \multirow{2}{*}{ Region } & \multirow{2}{*}{ Stock } & \multicolumn{2}{c}{ Sex } & \multirow{2}{*}{ Total } \\
\cline { 3 - 4 } East & Estuarine & 28 & 53 & 81 \\
& Barrier Island & 8 & 18 & 26 \\
& Coastal & 4 & 10 & 14 \\
& Estuarine & 10 & 12 & 22 \\
& Barrier Island & 22 & 19 & 41 \\
Total & Coastal & 7 & 14 & 21 \\
& & 51 & 73 & 124 \\
\hline
\end{tabular}



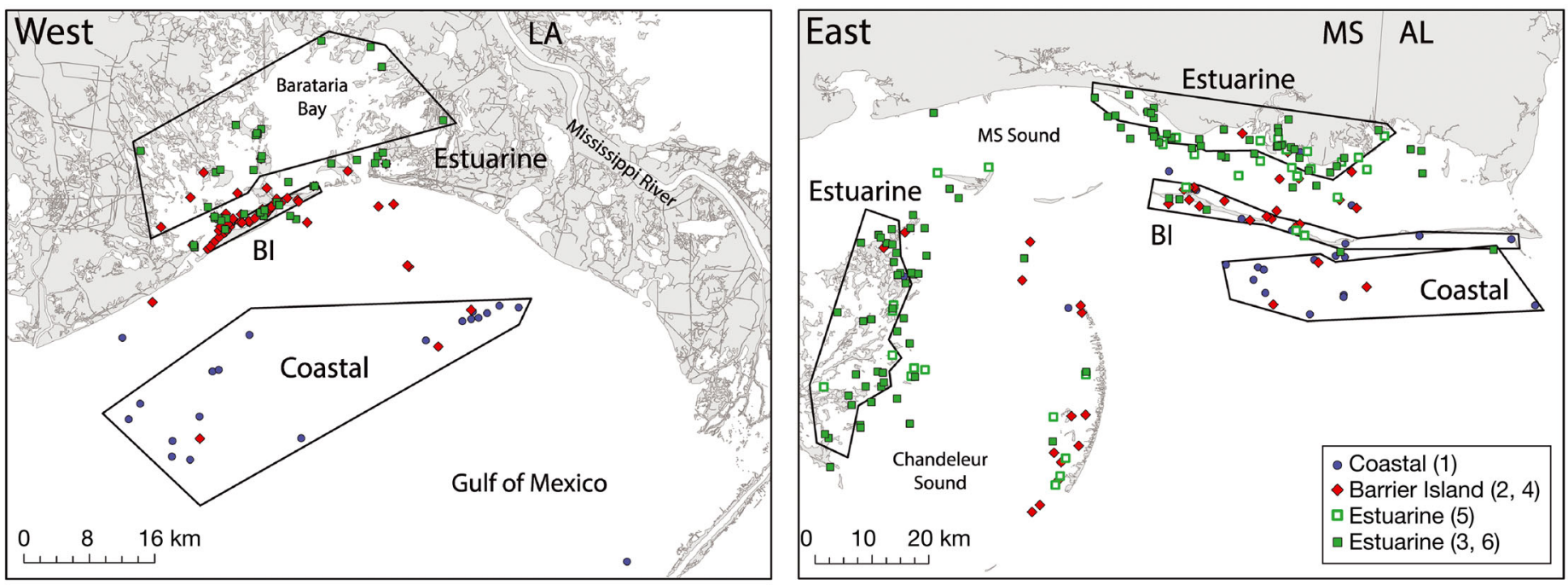

Fig. 2. Biopsy samples of common bottlenose dolphins Tursiops truncatus selected as part of the training dataset and the resultant predicted stock. Polygons encircle samples included in the training dataset, labeled to indicate 'observed' stock on the basis of location of sampling. Symbol shape and color indicate the predicted stock, Estuarine, Barrier Island (BI), or Coastal, resulting from the model output. For example, blue circles in the coastal polygon represent samples collected in the coastal area (observed Coastal) and assigned to the Coastal stock (predicted Coastal); red diamonds in the Coastal polygons represent samples collected in the coastal area but assigned to the BI stock. Biopsy samples external to the polygons were not included in the training dataset but could be assigned to stock on the basis of their $\delta^{13} \mathrm{C}$ and $\delta^{34} \mathrm{~S}$ values. The numbers (in parentheses) associated with the node names correspond to the nodes in the tree diagram (see Fig. 3). LA: Louisiana, MS: Mississippi, AL: Alabama

(overall range of 6.9-18.1; Table S2 in the Supplement). Of 45 pairwise comparisons (6 nodes, 3 isotopes), 37 were statistically significant after adjusting for multiple comparisons (SAS Proc Multtest, p-values adjusted using bootstrapping, significant p-values from $<0.0001$ to 0.045 ; Table S3 in the Supplement). Overall, isotopic values for all 3 elements were sequentially greater from Estuarine to BI to Coastal and from West to East, with significant positive correlations (SAS Proc Corr, Spearman correlation coefficients, all $\mathrm{p}<0.001$ ); the relative increase from Estuarine to BI to Coastal was greater in West than East (Fig. S1 in the Supplement). Within nodes, however, a significant correlation between $\delta^{13} \mathrm{C}$ and

Table 2. Within-sample confusion matrix for the training dataset of common bottlenose dolphin Tursiops truncatus samples. Rows are classification from the model, columns indicate the stock sampled. For example, 67 samples were collected from Barrier Islands (BI) while the model predicted 61 samples to be BI

\begin{tabular}{|lrrcr|}
\hline Stock & Estuarine & BI & Coastal & Total predicted \\
\hline Estuarine & 91 & 14 & 1 & 106 \\
BI & 9 & 46 & 6 & 61 \\
Coastal & 3 & 7 & 28 & 38 \\
Total observed & 103 & 67 & 35 & 205 \\
\hline
\end{tabular}

$\delta^{34} \mathrm{~S}$ occurred only for Coastal samples $(\mathrm{p}=0.04)$. Two estuarine nodes were identified in East (Estuarine(5) and Estuarine(6)). Estuarine(5) values were higher for $\delta^{13} \mathrm{C}$ and $\delta^{15} \mathrm{~N}$ and lower for $\delta^{34} \mathrm{~S}$ relative to Estuarine(6), but not different from East BI or Coastal. Overall in East, higher values occurred from BI to Coastal, but with no difference in $\delta^{13} \mathrm{C}$ or $\delta^{15} \mathrm{~N}$ from Estuarine(5) to Coastal or from Estuarine(6) to BI.

\section{Stranding samples}

\section{Effects of decomposition}

Carcasses exhibiting advanced decomposition (condition code 4 ) were distributed across 3 nodes, West BI $(n=6)$, West Estuarine(3) $(n=1)$, and East Estuarine(6) $(\mathrm{n}=4)$. Although the sample size was small, there was no significant difference within node (West $\mathrm{BI}$ and East Estuarine(6)) in mean stable isotope values for any of the isotopes (Welch's $t$-test, p-values ranged from 0.183 to 0.998 ) as a function of condition code, and there were no outlying values for the code 4 samples relative to samples from strandings of condition codes 1 to 3 (Table S4 in the Supplement). Therefore, code 4 samples were retained for the analyses. 


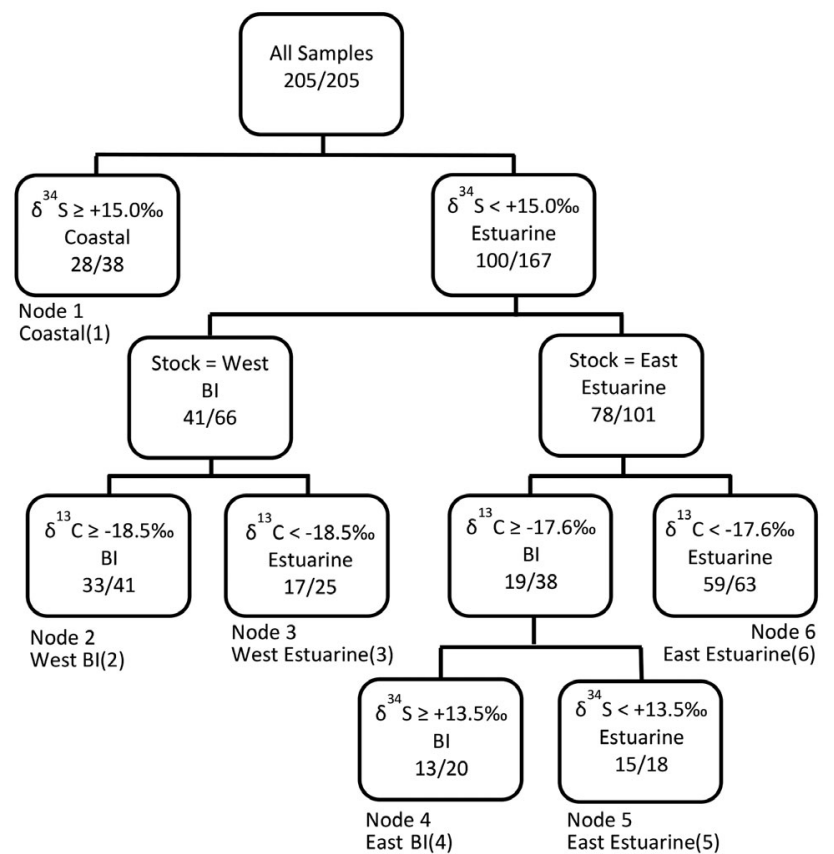

Fig. 3. Classification results from the recursive partition analysis using the training dataset of common bottlenose dolphins Tursiops truncatus. Within each box, the top row shows the splitting criterion, the second row indicates the primary stock membership (Estuarine, Barrier Island [BI] or Coastal), and the third row indicates the sample size, with the numerator giving the number of observations predicted to occur in that node and the denominator indicating the number of observed values from the training dataset. The 6 terminal nodes have been assigned node numbers and names to facilitate tracking of results in the text, tables, and other figures

Probability of Estuarine, BI, or Coastal

Stranding samples were collected from animals in areas that extended from western Louisiana to Choctawhatchee Bay, Florida (Fig. 1). Of the 217 stranded animals meeting the required criteria for analyses ( $\mathrm{n}=118$ East and $\mathrm{n}=99$ West), the model predicted 104, 41, and 72 to be Estuarine, BI, and Coastal, respectively, with estimated assignment probabilities of $0.473,0.172$, and 0.355 , respectively, for the combined sample. The distribution of predicted Estuarine, BI, and Coastal was not uniform. In particular, strandings in the westernmost area were predominantly Coastal. The habitat changes from west of Vermilion Bay, Louisiana, to the TexasLouisiana border, where the estuaries are smaller with limited access to the coast, there are no barrier islands, and only a single, small, estuarine population of dolphins occurs. Thus, for purposes of capturing these differences in the prediction of source habitat for strandings, West was further stratified into
Table 3. Probability of a stranded common bottlenose dolphin Tursiops truncatus being assigned to Estuarine (p(Estuarine)), Barrier Island (p(BI)), or Coastal (p(Coastal)) stock for the total sample, for the stranding sample stratified by region (East or West), and with West further stratified into central and western Louisiana (LA). Strandings assigned to the Coastal stock presumably belong to the Western Coastal Stock (West) or the Northern Coastal Stock (East)

\begin{tabular}{|lrccc|}
\hline Region of stranding & $\mathrm{N}$ & $\mathrm{p}$ (Estuarine) & $\mathrm{p}(\mathrm{BI})$ & $\mathrm{p}$ (Coastal) \\
\hline Total East and West & 217 & 0.36 & 0.17 & 0.47 \\
East only & 118 & 0.67 & 0.15 & 0.19 \\
West - central LA & 76 & 0.27 & 0.65 & 0.08 \\
West - western LA & 23 & 0.17 & 0.45 & 0.38 \\
& & & & \\
\hline
\end{tabular}

western Louisiana $(\mathrm{n}=23$; west of Vermilion Bay, Louisiana, to the Texas-Louisiana border) and central Louisiana ( $\mathrm{n}=76$; Vermillion Bay east to the MS River Delta). The highest probability of a stranded animal belonging to Estuarine occurred in the East and the highest probability of belonging to Coastal occurred in western Louisiana (Table 3, Fig. 4).

\section{Patterns among nodes}

Mean stable isotopes values across the 6 nodes ranged from -19.6 to $-16.3 \%$ o for $\delta^{13} \mathrm{C},+14.6$ to $16.5 \%$ for $\delta^{15} \mathrm{~N}$, and +10.9 to $16.9 \%$ for $\delta^{34} \mathrm{~S}$ (Table S5 in the Supplement). While constrained by parameters determined from the training dataset, some trends occurred in the stranding samples. Similar to the training dataset, $\delta^{13} \mathrm{C}$ and $\delta^{15} \mathrm{~N}$, but not $\delta^{34} \mathrm{~S}$, were significantly positively correlated overall (SAS Proc Corr, Spearman correlation coefficients, $\mathrm{p}<0.001$ ). Within node, however, significant correlations, all positive, occurred only within Coastal $\left(\delta^{13} \mathrm{C}\right.$ and $\left.\delta^{15} \mathrm{~N}\right)$ and BI (West BI: $\delta^{13} \mathrm{C}$ and $\delta^{15} \mathrm{~N}, \delta^{15} \mathrm{~N}$ and $\delta^{34} \mathrm{~S}$; East BI: $\delta^{13} \mathrm{C}$ and $\delta^{15} \mathrm{~N}$ only) nodes. In contrast to the training dataset, mean $\delta^{13} \mathrm{C}$ values for Coastal were intermediate between Estuarine and BI samples.

Some patterns also emerged within the defined East BSE stocks (Table 4). All strandings from Choctawhatchee and Pensacola Bays and half of the samples from Perdido Bay, the easternmost bays, were assigned to Estuarine(5), with those samples representing $60 \%$ of that node and $75 \%$ of strandings from those 3 BSE stocks. All of the Estuarine strandings in Mobile Bay, the MS River Delta, and Lake Pontchartrain, and $89 \%$ of those in Mississippi Sound, all locations west of the previously noted bays, were assigned to East Estuarine(6). Only Estuarine strandings from Perdido Bay, between the eastern and western 

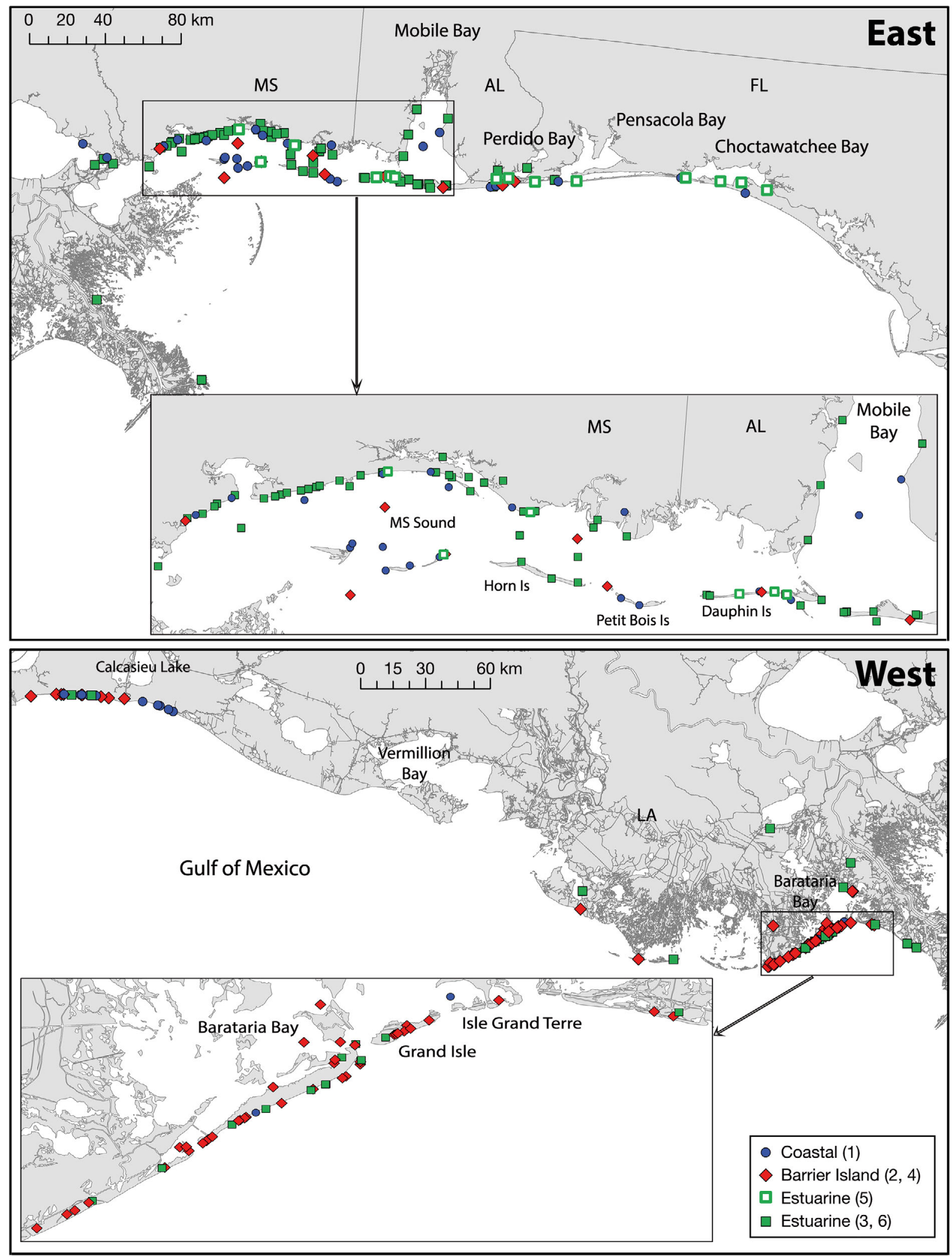

Fig. 4. Assignment of common bottlenose dolphin Tursiops truncatus strandings to Estuarine, Barrier Island, or Coastal stock predicted from the recursive partition analysis. The node names and numbers are as in Fig. 3 
Table 4. Comparison of assigned stock for strandings of common bottlenose dolphins Tursiops truncatus that occurred east of the Mississippi River Bird's Foot Delta. The Stock Assessment Report (SAR) (Waring et al. 2015) designation assigns the stranding to stock on the basis of stranding location. The recursive partition analysis predicted the classification from stable isotope values, assigning strandings to Estuarine, Barrier Island (BI), or Coastal stock. For example, of 12 total strandings in Mobile Bay, 2 were predicted to be from the Coastal stock even though the stranding was in the estuary; there was agreement that the remaining 10 strandings were Estuarine. The bay, sound, and estuarine stocks are listed geographically from east to west. The Northern Coastal Stock comprises strandings that occurred outside of defined bays, sounds, and estuaries. The node name and number refer to the classification tree in Fig. 3 (e.g. BI(4) refers to Node 4 East)

\begin{tabular}{|c|c|c|c|c|c|}
\hline \multirow{2}{*}{ SAR Stock } & \multirow[b]{2}{*}{ Coastal(1) } & \multicolumn{4}{|c|}{ Node } \\
\hline & & $\begin{array}{l}\text { East } \\
\mathrm{BI}(4)\end{array}$ & $\begin{array}{c}\text { East } \\
\text { Estuarine(5) }\end{array}$ & $\begin{array}{c}\text { East } \\
\text { Estuarine(6) }\end{array}$ & Total \\
\hline Choctawhatchee Bay, FL & & & 5 & & 5 \\
\hline Pensacola Bay, FL & & & 1 & & 1 \\
\hline Perdido Bay, FL and AL & & 1 & 3 & 2 & 6 \\
\hline Mobile Bay, AL & 2 & & & 10 & 12 \\
\hline Mississippi Sound, MS & 14 & 6 & 5 & 42 & 67 \\
\hline Mississippi River Delta, MS & & & & 3 & 3 \\
\hline Lake Pontchartrain, MS & 2 & & & 2 & 4 \\
\hline Northern Coastal & 9 & 3 & 1 & 7 & 20 \\
\hline Total & 27 & 10 & 15 & 66 & 118 \\
\hline
\end{tabular}

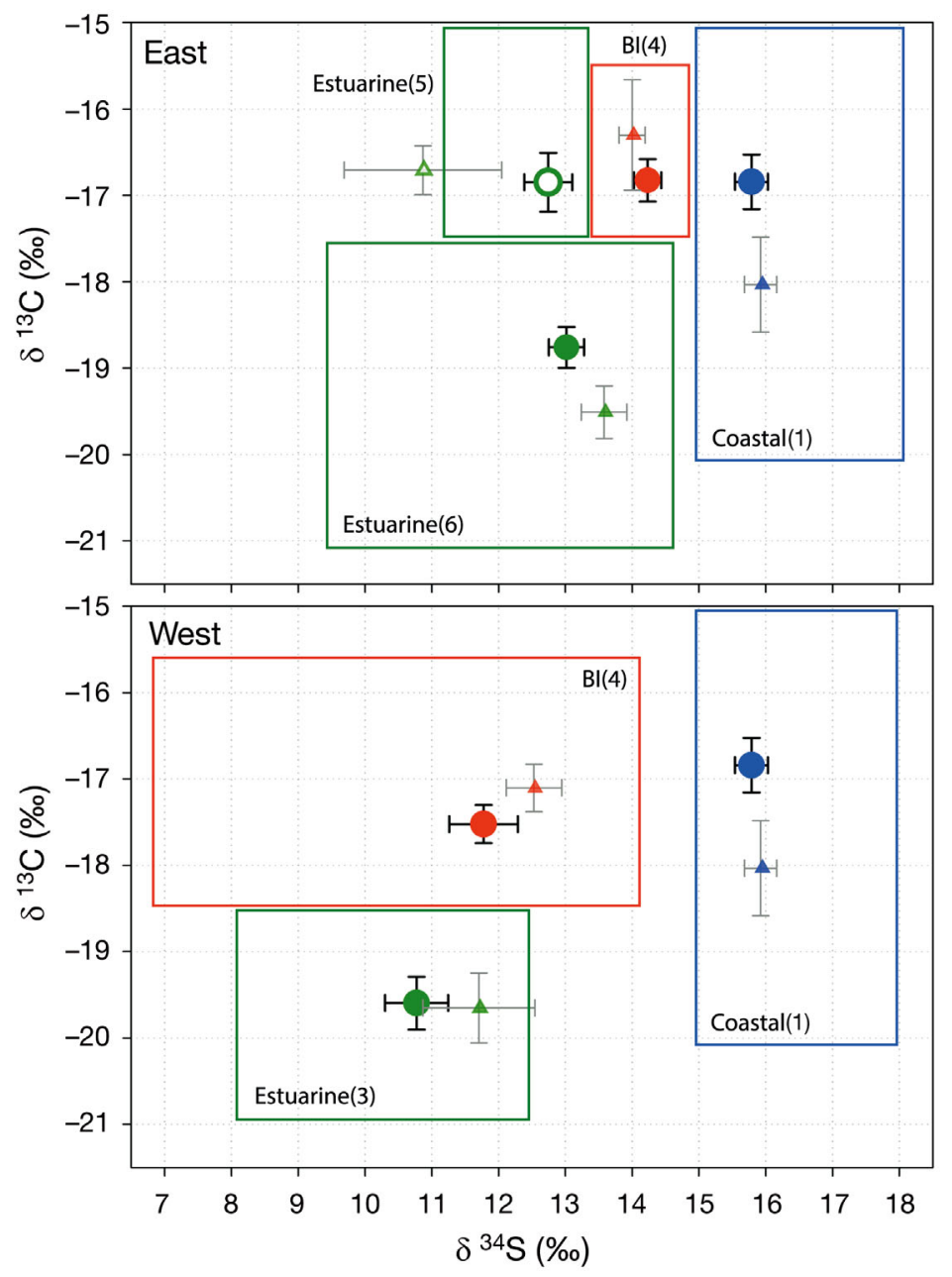

estuaries referenced above, were relatively evenly split between those 2 nodes, although the sample sizes were small.

Comparison of stable isotope values between live and stranded dolphins

Some variation occurred in isotopic values between samples from live (biopsy) and stranded animals (Fig. S2 in the Supplement). Within node, the range in values for all 3 stable isotope ratios was greater in stranded animals in 14 of 18 strata (3 isotopes, 6 nodes), as shown in the 2 elements, carbon and sulfur, that contributed to defining the stocks (Fig. S3 in the Supplement). Statistically significant differences occurred in the mean values between the training and stranding samples for 10 of 18 strata (SAS Proc Multtest, p-value adjusted using the bootstrap method, significant $\mathrm{p}$-values from $<0.0001$ to 0.0285$)$. Differences occurred most frequently for $\delta^{15} \mathrm{~N}$, occurring at 4 nodes, with a fifth node almost significant $(\mathrm{p}=0.052)$, thus excluding only Coastal; in all but one of those 5 nodes, the stranding sample had higher $\delta^{15} \mathrm{~N}$ values than the biopsy sample, with differences ranging from 0.31 to $1.34 \%$ of a total range in $\delta^{15} \mathrm{~N}$ across all samples of $5 \%$ o). Consistent differences between biopsy and stranding samples (e.g. stranding samples generally heavier or lighter) were not detected for $\delta^{13} \mathrm{C}$ and $\delta^{34} \mathrm{~S}$ (Fig. 5). Overlap between West BI and East Estuarine(5) was sufficient to have caused misassignment to node in the absence of first accounting for region.

Fig. 5. Within-node comparison of stable isotope values between biopsy training samples and samples from stranded common bottlenose dolphins Tursiops truncatus. The mean is denoted with a symbol (circle for training subsample from biopsies; triangle for strandings); the error bars represent the upper and lower $95 \%$ confidence limits of the mean. The outline of the boxes indicates the isotope space, i.e. the range of stable isotope ratio values for carbon and sulfur, for each node from the training sample. The node names and numbers are as in Fig. 3 


\section{DISCUSSION}

For carbon, nitrogen, and sulfur, stable isotope values fell within expected ranges for secondary consumers, in this case bottlenose dolphins, in estuarine and nearshore habitats. $\delta^{13} \mathrm{C}$ values were consistent with the range of values typically found in benthic micro- and macroalgae and marine microalgae; values at estuarine sites were lower in $\delta^{13} \mathrm{C}$ compared to coastal sites, with BI values intermediate, suggesting spatial mixing of brackish and marine water masses and associated carbon sources at BI sites (Currin et al. 1995, Chanton \& Lewis 2002, Garcia et al. 2007). The ranges of $\delta^{13} \mathrm{C}$ values in dolphins were similar to those in skin samples from estuarine and nearshore bottlenose dolphins from other sites, e.g. Florida (Wilson et al. 2012, Browning et al. 2014a) and Australia (Ansmann et al. 2015). These $\delta^{13} \mathrm{C}$ values were enriched compared to values found in oil-derived materials associated with the DWH oil spill, which are typically near $-27 \%$, reflecting deltaic origins (Chung et al. 1992, W. Graham et al. 2010, Carmichael et al. 2012b). Given the 5 to $10 \%$ enrichment in dolphin skin compared to oil sources, it is likely that dolphins assimilated little or no dietary $\mathrm{C}$ from oil-derived sources. This finding does not mean that dolphins did not ingest oil materials but that it was not a significant component of their assimilated diet during the 6 to $8 \mathrm{wk}$ (skin turnover rate, Browning et al. 2014 b) prior to sampling. $\delta^{15} \mathrm{~N}$ values were consistent with the range of values found in other studies reflecting the trophic level of prey for coastal and estuarine bottlenose dolphins (Barros \& Wells 1998, Gannon \& Waples 2004, Wilson et al. 2013). However, $\delta^{15} \mathrm{~N}$ values vary with type of local nutrient loading (Macko \& Ostrom 1994, Schlacher et al. 2005), which can confound interpretation of $\delta^{15} \mathrm{~N}$ values and may account for some of the differences among nodes (Rossman et al. 2013). $\delta^{34}$ S values were consistent with expected increases in salinity from freshwater to marine systems (Peterson et al. 1986, Fry \& Chumchal 2011). Although $\delta^{34} \mathrm{~S}$ is less frequently used as a tracer than $\delta^{13} \mathrm{C}$ or $\delta^{15} \mathrm{~N}$, the additional power of $\delta^{34} \mathrm{~S}$ to discriminate sources based on salinity was essential for assigning dolphins stranded after the oil spill to coastal or BSE stocks.

The high probability $(80.5 \%)$ of correct assignment to Estuarine, BI, or Coastal stock indicates predictable variation in stable isotopes within each region and fidelity to habitat within the time frame represented in the skin sample. Stable isotope data have demonstrated habitat residency of invertebrates and fish across a number of studies in the northern GoM.
Samples from 118 species of benthic fish from the estuarine waters of Barataria Bay, Louisiana, to lower saline waters further north in the river systems, formed 4 distinct isotopic groups also primarily based on stable isotope ratios of carbon and sulfur (Fry 2002). Using stable isotopes of sulfur, Fry \& Chumchal (2011) were able to identify transience and residence in more than 60 species of fish, including known prey of bottlenose dolphins (Barros \& Wells 1998), from less saline to more saline areas in Barataria Bay and Breton Sound, located west and east, respectively, of the MS River Delta. From 9 sites bordering Mississippi Sound, Comyns et al. (2008) identified differences in stable isotopes of carbon and oxygen, along with 5 trace elements, in spotted seatrout Cynoscion nebulosus. Assignment probability was greater than $90 \%$ for 6 of the sites and greater than $70 \%$ for the remaining 3 sites, with $\delta^{13} \mathrm{C}$ and $\delta^{18} \mathrm{O}$ showing the highest regional affinities. Adjacent sites were within tens of kilometers. On a finer scale, juvenile gray snapper Lutjanus griseus had a correct assignment probability of $80 \%$ to nursery sites within $10 \mathrm{~km}$ of each other in the Florida Keys, also using $\delta^{13} \mathrm{C}$ and $\delta^{18} \mathrm{O}$. Stable isotope values of carbon and sulfur from fish sampled across 10 sites in the eastern panhandle of Florida (among estuarine, nearshore, and offshore waters) resulted in a correct classification rate of $73 \%$ (Wilson et al. 2013). Using results from fish collected from known locations as training data, Wilson et al. (2013) applied the model to samples from dolphins, resulting in $89 \%$ of dolphins (16 of 18) sampled from one of the estuarine systems correctly classified to that estuary. The assignment probabilities for the training sample from the current study are similar to those for fish and dolphins from the same or nearby areas in the northern GoM.

Linear covariation between $\delta^{13} \mathrm{C}$ and $\delta^{15} \mathrm{~N}$ is a characteristic of marine systems (Kelly 2000). More specifically, in the northern GoM, increasing values of $\delta^{13} \mathrm{C}, \delta^{15} \mathrm{~N}$, and $\delta^{34} \mathrm{~S}$ from more estuarine to more coastal habitats have been reported in a number of fish studies (Clementz \& Koch 2001, Wissel \& Fry 2005, Fry \& Chumchal 2011, Fulford \& Dillon 2013, Olsen et al. 2014). Increases of more than $4 \%$ for $\delta^{13} \mathrm{C}$ and $\delta^{34} \mathrm{~S}$ have been found in a range of species from 5 stations in Apalachicola Bay, Florida, spanning from the upper estuary of the Apalachicola River to mid-bay to a coastal reef site (Chanton \& Lewis 2002). Fry (2002) reported enrichment in $\delta^{13} \mathrm{C}$ and $\delta^{34} \mathrm{~S}$ in 118 species of benthic fish from the Mississippi River (freshwater) to the brackish waters of Barataria Bay (average increase in $\delta^{13} \mathrm{C}$ of $6 \%$ and in 
$\delta^{34} \mathrm{~S}$ of over $11 \%$ ). Sulak et al. (2012) compared $\delta^{13} \mathrm{C}$, $\delta^{15} \mathrm{~N}$, and $\delta^{34} \mathrm{~S}$ in multiple species of fish from riverine freshwater habitats to marine habitats in western Florida; $\delta^{13} \mathrm{C}$ increased from a range of -17.2 to $-20.3 \%$ in estuarine species to -15.0 to $-17.7 \%$ in coastal GoM species, and $\delta^{34} \mathrm{~S}$ increased from a range of about 11.0 to $20 \%$ from estuarine to coastal species, respectively. The linear covariation between $\delta^{13} \mathrm{C}$ and $\delta^{15} \mathrm{~N}$ found in the current study was consistent with previous reports, although the magnitude of enrichment was lower (maximum differences of 3 , 2 , and $5 \%$ for $\delta^{13} \mathrm{C}, \delta^{15} \mathrm{~N}$, and $\delta^{34} \mathrm{~S}$, respectively, between mean values) compared to fish studies. This difference may be due, in part, to fish sampled in very low salinity areas where bottlenose dolphins typically spend less time (Hornsby et al. 2017, this Theme Section).

In bottlenose dolphins from the GoM coast of Florida, similar trends were found in stable isotope values among habitats. Samples from coastal and offshore dolphins had higher $\delta^{15} \mathrm{~N}$ values than estuarine samples $\left(+1.5\right.$ to $2.5 \%$ ), and $\delta^{34} \mathrm{~S}$ values were progressively higher from estuarine to coastal to offshore (by approximately 4 and $5 \%$, respectively; Barros et al. 2010). The magnitude of increase for Florida dolphins was similar to dolphins from the northern GoM coast for $\delta^{15} \mathrm{~N}$, while the range for $\delta^{34} \mathrm{~S}$ was much greater for Florida animals, reflecting relatively low $\delta^{34} \mathrm{~S}$ values in the Florida estuary, Sarasota Bay, relative to Barataria Bay and Mississippi Sound. Further, $\delta^{13} \mathrm{C}$ was higher in Sarasota Bay relative to both coastal and oceanic samples from Florida and samples from the northern GoM coast. The relatively low $\delta^{34} \mathrm{~S}$ and high $\delta^{13} \mathrm{C}$ values in Sarasota Bay were due to the influence of extensive seagrass habitat (Fry et al. 1982, Trust \& Fry 1992, Hemminga \& Mateo 1996, Connolly et al. 2004, Barros et al. 2010, Rossman et al. 2013). Seagrass habitats are common in Sarasota Bay and have a variable presence in some of the western Florida Panhandle bays (Yarbro \& Carlson 2013) but are less common in both Mississippi Sound and Barataria Bay (Handley 2011). Nonetheless, along the GoM coast of Florida and the northern GoM, sulfur isotopes were the most diagnostic for distinguishing estuarine or nearshore and barrier island dolphins from coastal or offshore dolphins.

Differences were found in stable isotope values in samples from stranded dolphins relative to the biopsy samples. The most consistent difference was higher $\delta^{15} \mathrm{~N}$ values in skin from stranded dolphins. One proposed cause of $\delta^{15} \mathrm{~N}$ increase is protein catabolism resulting from nutritional stress, which might be expected for stranded animals nutritionally compro- mised before stranding. Following the DWH spill, animals were known to be in poor body condition (Schwacke et al. 2014), and it has been speculated that altered or reduced food resources due to the spill could have contributed to this (Carmichael et al. 2012a, Schwacke et al. 2014). It is also possible that poor condition and physiological impairment could have affected the ability to find or capture prey following the spill (Carmichael et al. 2012a). Both of these scenarios could result in catabolic conditions and concomitant increases in $\delta^{15} \mathrm{~N}$ values in stranded animals. However, the evidence for increases in $\delta^{15} \mathrm{~N}$ values due to starvation or nutritional stress is mixed. In a meta-analysis of published literature, Hertz et al. (2015) concluded that $\delta^{15} \mathrm{~N}$ values significantly increase due to nutritional restriction. In contrast, no significant differences in $\delta^{15} \mathrm{~N}$ values were found between stranded and bycaught harbor porpoises Phocoena phocoena in the North Sea exhibiting poor, moderate, or good body condition (Das et al. 2004), and no change was found in muscle from striped dolphins Stenella coeruleoalba with low lipid content in blubber (Gómez Campos et al. 2011). A significant but small decrease in $\delta^{15} \mathrm{~N}$ values was found in fin whales Balaenoptera physalus during the normal fasting that occurs during migration (Aguilar et al. 2014). Aguilar et al. (2014) suggested that the response to fasting by mammals with massive lipid reserves and limited access to drinking water, such as mysticetes, may represent a special case not directly applicable to birds and terrestrial mammals, while Gómez Campos et al. (2011) suggested that striped dolphins may undergo interim conditions of nutritional stress but do not experience strong, seasonal limitations in feeding that would lead to muscle catabolism. In contrast, BSE dolphins tend to be resident or make only relatively small or short-term movements (Wells et al. 2017), without a fasting stage. Thus, whether nutritional stress results in an increase in $\delta^{15} \mathrm{~N}$ values may depend on the underlying life history of a particular species. Additional studies may help confirm whether elevated $\delta^{15} \mathrm{~N}$ values in stranded BSE bottlenose dolphins was indicative of nutritional stress prior to stranding.

The increased variance in and range of isotopic values in stranded dolphins also suggests that some stranded animals originated from source populations not included in the training sample. While estuarine-resident bottlenose dolphins in the northern GoM generally exhibit site fidelity, movements beyond primary habitats have been documented. Paternity studies of bottlenose dolphins in Sarasota Bay, Florida, showed that approximately $15 \%$ of 
calves were sired by non-resident males (Duffield \& Wells 2002). Of 10 bottlenose dolphins radio-tagged in Matagorda Bay, Texas, 7 exhibited confined movements near the tagging site, while 3 (tag life 21-59 d) ranged into adjacent bays, with 1 animal spending about half its time outside Matagorda Bay (Lynn \& Würsig 2002). Of 23 bottlenose dolphins radio-tagged near St. Joe Bay, Florida, 19 remained fully or predominantly in the focal survey region (Balmer et al. 2008), while 1 dolphin travelled about $100 \mathrm{~km}$ to Destin, Florida, and 2 were sighted in Mississippi Sound, more than $300 \mathrm{~km}$ from St. Joe Bay (Balmer et al. 2016). It was subsequently proposed that the latter 3 dolphins belonged to the coastal stock, despite having been tagged or photoidentified in an estuary. Seasonal fluctuations in abundance of dolphins in BSE along the GoM coast have been attributed to dolphins from coastal stocks periodically venturing into BSE waters (e.g. Hubard et al. 2004, Balmer et al. 2008, Conn et al. 2011), and the tagged dolphins from St. Joe Bay apparently support that hypothesis (Balmer et al. 2016). From photo-ID studies in Choctawhatchee and Pensacola Bays (easternmost bays within the area most affected by the DWH oil spill), 650 individual dolphins were identified; $88 \%$ were considered resident, and the remainder were considered transients on the basis of resightings (Shippee 2014). Of 44 satellite-tagged bottlenose dolphins in Barataria Bay, half ventured into nearshore waters of the GoM, spending, on average, $5.7 \%$ of their time outside the estuary (Wells et al. 2017). Such movements could affect the isotopic composition of dolphins, the degree to which would depend on where and for how long dolphins underwent inter-estuarine or coastal movements.

Underlying seasonal changes in the environment or seasonal changes in dolphin diet would also affect the stable isotope composition (Browning et al. 2014b, Ansmann et al. 2015). Seasonal variation in values of $\delta^{13} \mathrm{C}$ and $\delta^{15} \mathrm{~N}$ has been reported in sediments, organic matter, and primary producers in cold- and warm-water estuaries (Ostrom et al. 1997, Vizzini \& Mazzola 2003, Bergamino et al. 2014) and in lakes (Perga \& Gerdeaux 2005). In a comparison of 2 tidal rivers along the central GoM coast of Florida, seasonal changes in $\delta^{13} \mathrm{C}$ and $\delta^{15} \mathrm{~N}$ occurred in primary and secondary consumers, but not higher trophic levels (Olin et al. 2013). In Mississippi Sound, increases in both $\delta^{13} \mathrm{C}$ (by about $4 \%$ ) and $\delta^{15} \mathrm{~N}$ (by about $2 \%$ ) occurred from summer to fall in spotted seatrout (Fulford \& Dillon 2013). Seasonal differences found in several species of fish collected in Pensacola and Choctawhatchee Bays, Florida, were also reflected in skin samples from resident dolphins (Worthy et al. 2013). Perga \& Gerdeaux (2005) reported that the seasonal changes in $\delta^{13} \mathrm{C}$ and $\delta^{15} \mathrm{~N}$ of prey were reflected in liver tissue, with high turnover, but not in muscle, with lower turnover, of whitefish Coregonus lavaretus during autumn and winter when fish somatic growth was limited. Given the magnitude of some of the seasonal variation reported elsewhere, it is possible that incorporating season as a predictor variable in the current study would have increased the probability of correct assignment to stock for dolphins from the northern GoM coast, but the seasonal distribution of existing samples was insufficient. Future use of stable isotopes for similar studies may benefit from consideration of season during experimental design.

Two additional factors, tissue turnover rate and decomposition, may also affect the variability and range of stable isotope values in our samples. The stable isotope values in skin samples represent the time-averaged integration of assimilated stable isotopes. Browning et al. (2014b) were able to determine experimentally that the mean $( \pm \mathrm{SE})$ half-lives of $\delta^{13} \mathrm{C}$ and $\delta^{15} \mathrm{~N}$ in epidermis were $13.9 \pm 4.8$ and $15.3 \pm 1.7 \mathrm{~d}$, respectively. Thus, isotopic values in dolphin skin represent prey consumption for a relatively short period of time, 6 to $8 \mathrm{wk}$, especially given the mobility of the dolphins. For example, an individual dolphin moving between 2 habitats containing prey with different isotopic values would be expected to maintain an isotopic composition intermediate between the compositions of resident dolphins from either 2 habitats, if sampling occurred within the 6 to $8 \mathrm{wk}$ turnover time of skin. The effect may be predicted assignment to the wrong habitat or a decrease in precision in assignment probabilities (Thomas et al. 2017, this Theme Section). Samples from stranded animals reflect a range of tissue quality as a result of decomposition. In skin-plus-muscle samples from 3 fresh-dead striped dolphins left outside to decompose from 0 to $62 \mathrm{~d}$, during which time the tissue decomposed from condition code 2 (fresh) to code 4 (advanced decomposition; Geraci \& Lounsbury 2005), no difference was found in the isotope composition of carbon or nitrogen (Payo-Payo et al. 2013). Our results support that decomposition may not be a large source of variability in stable isotope signatures, although sample sizes were small in both studies.

Despite the sources of variability and uncertainty, stable isotope compositions were useful for differentiating Estuarine, BI, and Coastal dolphins in the 
northern GoM. The identification of separate BI and Estuarine groups in the current study is consistent with data from recent telemetry (Wells et al. 2017, K. D. Mullin et al. unpubl. data) and genetics (Rosel et al. 2017) studies. Overall, stable isotope ratios have proven useful to differentiate groups of dolphins at relatively fine scales among seasons and sites, even at some sites within the same estuaries (Worthy et al. 2013, Shippee 2014). Stable isotope values cannot address demographic independence, and, for many tissues, represent only a short-term signal of habitat preferences or prey. Nevertheless, stable isotope analyses are relatively inexpensive and fast, facilitating use of results to provide guidance regarding where genetic or other demographic testing is warranted. In addition, stable isotope ratios may aid in determining the source habitat of stranded dolphins, further increasing the value of biological data collected from strandings.

Acknowledgments. This study was conducted as part of, and was funded by, the Deepwater Horizon NRDA investigation, which was cooperatively conducted by NOAA, other Federal and State Trustees, and BP. The scientific results and conclusions of this publication, as well as any views or opinions expressed herein, are those of the authors and do not necessarily represent the view of NOAA or any other natural resource Trustee for the BP/Deepwater Horizon NRDA. We thank the members of the Marine Mammal Stranding Network (MMSN) in the northern GoM for their tireless efforts during a large and long UME. We appreciate the willingness of Gulf World to provide samples although ultimately their area of coverage was outside the range of this study. Staff from the Southeast Fisheries Science Center laboratories and National Center for Coastal Ocean Science Hollings Marine Laboratory were instrumental in obtaining stranding data and biopsy samples during health assessments or vessel surveys. We appreciate the input of other members of the Population Quantification Team, Brian Balmer, Cormac Booth, Lance Garrison, Fawn Hornsby, Nick Kellar, Trent McDonald, Keith Mullin, Patricia Rosel, Teri Rowles, and Randall Wells, and the statistics review team, Phil Dixon, Jay Ver Hoef, Tomo Eguchi, Trent McDonald, Robin Waples, and Ailsa Hall. The manuscript was reviewed by Colleen Bryan, Alex Chester, Steven Christopher, Jessica Reiner, all from NOAA, and 2 anonymous reviewers. Barbie Byrd, NOAA Beaufort Lab, assisted with preparation of the figures. Remote biopsy samples were collected under Marine Mammal Protection Act (MMPA) Permit No. 14450 and those collected during health assessments were collected under MMPA Permit No. 932-1905/MA-009526, both issued by NMFS. Protocols were reviewed and approved by the NOAA Institutional Animal Care and Use Committee. Response to cetacean stranding events is conducted by MMSN authorized under Section 112c (Stranding Agreements from the NMFS regional offices) or Section 109h (Federal, State, or local government officials) of the MMPA. This publication does not constitute an endorsement of any commercial product or intend to be an opinion beyond scientific or other results obtained by NOAA.

\section{LITERATURE CITED}

Aguilar A, Giménez J, Gómez-Campos E, Cardona L, Borrell A (2014) $\delta^{15} \mathrm{~N}$ value does not reflect fasting in mysticetes. PLOS ONE 9:e92288

Ansmann IC, Parra GJ, Lanyon JM, Seddon JM (2012) Finescale genetic population structure in a mobile marine mammal: inshore bottlenose dolphins in Moreton Bay, Australia. Mol Ecol 21:4472-4485

Ansmann IC, Lanyon JM, Seddon JM, Parra GJ (2015) Habitat and resource partitioning among Indo-Pacific bottlenose dolphins in Moreton Bay, Australia. Mar Mamm Sci 31:211-230

Aurioles-Gamboa D, Rodríguez-Pérez MY, Sánchez-Velasco L, Lavín MF (2013) Habitat, trophic level, and residence of marine mammals in the Gulf of California assessed by stable isotope analysis. Mar Ecol Prog Ser 488:275-290

Baird RW, Gorgone AM, McSweeney DJ, Ligon AD and others (2009) Population structure of island-associated dolphins: evidence from photo-identification of common bottlenose dolphins (Tursiops truncatus) in the main Hawaiian Islands. Mar Mamm Sci 25:251-274

Balmer B, Wells R, Nowacek S, Nowacek D, Schwacke L, McLellan W, Scharf F (2008) Seasonal abundance and distribution patterns of common bottlenose dolphins (Tursiops truncatus) near St. Joseph Bay, Florida, USA. J Cetacean Res Manag 10:157-167

Balmer B, Sinclair C, Speakman T, Quigley B and others (2016) Extended movements of common bottlenose dolphins (Tursiops truncatus) along the northern Gulf of Mexico's central coast. Gulf Mex Sci 33:93-97

*Barros N, Wells R (1998) Prey and feeding patterns of resident bottlenose dolphins (Tursiops truncatus) in Sarasota Bay, Florida. J Mammal 79:1045-1059

* Barros NB, Ostrom P, Stricker C, Wells R (2010) Stable isotopes differentiate bottlenose dolphins off west-central Florida. Mar Mamm Sci 26:324-336

Bassos-Hull K, Perrtree R, Shepard C, Schilling S and others (2013) Long-term site fidelity and seasonal abundance estimates of common bottlenose dolphins (Tursiops truncatus) along the southwest coast of Florida and responses to natural perturbations. J Cetacean Res Manag 13: 19-30

Ken-David M, Flaherty EA (2012) Stable isotopes in mammalian research: a beginner's guide. J Mammal 93: 312-328

* Bergamino L, Dalu T, Richoux NB (2014) Evidence of spatial and temporal changes in sources of organic matter in estuarine sediments: stable isotope and fatty acid analyses. Hydrobiologia 732:133-145

* Borrell A, Aguilar A, Tornero V, Sequeira M, Fernandez G, Alis S (2006) Organochlorine compounds and stable isotopes indicate bottlenose dolphin subpopulation structure around the Iberian Peninsula. Environ Int 32: 516-523

* Borrell A, Velásquez V, Pinela A, Kinze C, Lockyer C, Vighi M, Aguilar A (2013) Stable isotopes provide insight into population structure and segregation in eastern North Atlantic sperm whales. PLOS ONE 8:e82398

* Bräger S, Würsig B, Acevedo A, Henningsen T (1994) Association patterns of bottlenose dolphins (Tursiops truncatus) in Galveston Bay, Texas. J Mammal 75:431-437

* Browning N, McCulloch S, Bossart G, Worthy G (2014a) Fine-scale population structure of estuarine bottlenose dolphins (Tursiops truncatus) assessed using stable iso- 
tope ratios and fatty acid signature analyses. Mar Biol 161:1307-1317

Browning NE, Dold C, Jack IF, Worthy GA (2014b) Isotope turnover rates and diet-tissue discrimination in skin of ex situ bottlenose dolphins (Tursiops truncatus). J Exp Biol 217:214-221

Byrd BL, Hohn AH, Munden FH, Lovewell GN, Lo Piccolo RE (2008) Effects of commercial fishing regulations on stranding rates of bottlenose dolphin (Tursiops truncatus). Fish Bull 106:72-81

Byrd B, Hohn A, Lovewell G, Altman K and others (2014) Strandings as indicators of marine mammal biodiversity and human interactions off the coast of North Carolina. Fish Bull 112:1-23

Campbell L, Venkiteswaran J, Bond AL (2014) Common mistakes in stable isotope terminology and phraseology. https://figshare.com/articles/Common_Mistakes_in_ Stable_Isotope_Terminology_and_Phraseology/1150337

Carmichael RH, Graham WM, Aven A, Worthy G, Howden S (2012a) Were multiple stressors a 'perfect storm' for northern Gulf of Mexico bottlenose dolphins (Tursiops truncatus) in 2011? PLOS ONE 7:e41155

* Carmichael RH, Jones AL, Patterson HK, Walton WC II and others (2012b) Assimilation of oil-derived elements by oysters due to the Deepwater Horizon oil spill. Environ Sci Technol 46:12787-12795

* Chanton J, Lewis FG (2002) Examination of coupling between primary and secondary production in a riverdominated estuary: Apalachicola Bay, Florida, USA. Limnol Oceanogr 47:683-697

Charlton-Robb K, Taylor A, McKechnie S (2015) Population genetic structure of the Burrunan dolphin (Tursiops australis) in coastal waters of south-eastern Australia: conservation implications. Conserv Genet 16:195-207

Chung H, Rooney M, Toon M, Claypool GE (1992) Carbon isotope composition of marine crude oils (1). Am Assoc Pet Geol Bull 76:1000-1007

Clementz M, Koch P (2001) Differentiating aquatic mammal habitat and foraging ecology with stable isotopes in tooth enamel. Oecologia 129:461-472

Colegrove KM, Venn-Watson S, Litz J, Kinsel MJ and others (2016) Fetal distress and in utero pneumonia in perinatal dolphins during the Northern Gulf of Mexico unusual mortality event. Dis Aquat Org 119:1-16

Comyns BH, Rakocinski CF, Peterson MS, Shiller AM (2008) Otolith chemistry of juvenile spotted seatrout Cynoscion nebulosus reflects local natal regions of coastal Mississippi, USA. Mar Ecol Prog Ser 371:243-252

Conn PB, Gorgone AM, Jugovich AR, Byrd BL, Hansen LJ (2011) Accounting for transients when estimating abundance of bottlenose dolphins in Choctawhatchee Bay, Florida. J Wildl Manag 75:569-579

Connolly RM, Guest MA, Melville AJ, Oakes JM (2004) Sulfur stable isotopes separate producers in marine foodweb analysis. Oecologia 138:161-167

* Crawford K, McDonald RA, Bearhop S (2008) Applications of stable isotope techniques to the ecology of mammals. Mammal Rev 38:87-107

Currin CA, Newell SY, Paerl HW (1995) The role of standing dead Spartina alterniflora and benthic microalgae in salt marsh food webs: considerations based on multiple stable isotope analysis. Mar Ecol Prog Ser 121:99-116

Das K, Holsbeek L, Browning J, Siebert U, Birkun A, Bouquegneau JM (2004) Trace metal and stable isotope measurements $\left(\delta^{13} \mathrm{C}\right.$ and $\left.\delta^{15} \mathrm{~N}\right)$ in the harbour porpoise
Phocoena phocoena relicta from the Black Sea. Environ Pollut 131:197-204

Duffield DA, Wells RS (2002) The molecular profile of a resident community of bottlenose dolphins, Tursiops truncatus. In: Pfeiffer CJ (ed) Cell and molecular biology of marine mammals. Krieger Publishing, Melbourne, FL, p 3-11

DWH NRDA (Deepwater Horizon Natural Resource Damage Assessment) Trustees (2016) Deepwater Horizon oil spill: final programmatic damage assessment and restoration plan and final programmatic environmental impact statement. www.gulfspillrestoration.noaa.gov/ restoration-planning/gulf-plan (accessed 11 March 2016)

*Evans K, Thresher R, Warneke R, Bradshaw C, Pook M, Thiele D, Hindell M (2005) Periodic variability in cetacean strandings: links to large-scale climate events. Biol Lett 1:147-150

Fazioli KL, Hofmann S, Wells RS (2006) Use of Gulf of Mexico coastal waters by distinct assemblages of bottlenose dolphins (Tursiops truncatus). Aquat Mamm 32:212-222

Fernandez S, Hohn AA (1998) Age, growth, and calving season of bottlenose dolphins, Tursiops truncatus, off coastal Texas. Fish Bull 96:357-365

*Fernández R, García-Tiscar S, Santos MB, López A, Martínez-Cedeira JA, Newton J, Pierce GJ (2011) Stable isotope analysis in two sympatric populations of bottlenose dolphins Tursiops truncatus: evidence of resource partitioning? Mar Biol 158:1043-1055

*Fernández R, MacLeod C, Pierce G, Covelo P and others (2013) Inter-specific and seasonal comparison of the niches occupied by small cetaceans off north-west Iberia. Cont Shelf Res 64:88-98

Fruet PF, Secchi ER, Daura-Jorge F, Vermeulen E and others (2014) Remarkably low genetic diversity and strong population structure in common bottlenose dolphins (Tursiops truncatus) from coastal waters of the southwestern Atlantic Ocean. Conserv Genet 15:879-895

Fry B (2002) Conservative mixing of stable isotopes across estuarine salinity gradients: a conceptual framework for monitoring watershed influences on downstream fisheries production. Estuaries 25:264-271

Fry B, Chumchal MM (2011) Sulfur stable isotope indicators of residency in estuarine fish. Limnol Oceanogr 56: 1563-1576

Fry B, Scalan RS, Winters JK, Parker PL (1982) Sulphur uptake by salt grasses, mangroves, and seagrasses in anaerobic sediments. Geochim Cosmochim Acta 46: 1121-1124

Fulford RS, Dillon K (2013) Quantifying intrapopulation variability in stable isotope data for spotted seatrout (Cynoscion nebulosus). Fish Bull 111:111-121

*Gannon DP, Waples DM (2004) Diets of coastal bottlenose dolphins from the US mid-Atlantic coast differ by habitat. Mar Mamm Sci 20:527-545

* Garcia AM, Hoeinghaus DJ, Vieira JP, Winemiller K (2007) Isotopic variation of fishes in freshwater and estuarine zones of a large subtropical coastal lagoon. Estuar Coast Shelf Sci 73:399-408

Gaspari S, Holcer D, Mackelworth P, Fortuna C and others (2015) Population genetic structure of common bottlenose dolphins (Tursiops truncatus) in the Adriatic Sea and contiguous regions: implications for international conservation. Aquat Conserv 25:212-222

Geraci JR, Lounsbury VJ (2005) Marine mammals ashore: a field guide for strandings. National Aquarium in Balti- 
more, Baltimore, MD

Giménez J, Gómez Campos E, Borrell A, Cardona L, Aguilar A (2013) Isotopic evidence of limited exchange between Mediterranean and eastern North Atlantic fin whales. Rapid Commun Mass Spectrom 27:1801-1806

Gómez Campos E, Borrell A, Aguilar A (2011) Nitrogen and carbon stable isotopes do not reflect nutritional condition in the striped dolphin. Rapid Commun Mass Spectrom 25:1343-1347

Graham BS, Koch PL, Newsome SD, McMahon KW, Aurioles D (2010) Using isoscapes to trace the movements and foraging behavior of top predators in oceanic ecosystems. In: West JB, Bowen GJ, Dawson TE, Tu KP (eds) Isoscapes: understanding movement, pattern, and process on Earth through isotope mapping. Springer, Dordrecht, p 299-318

* Graham WM, Condon RH, Carmichael RH, Isabella D, Patterson HK, Linn LJ, Hernandez FJ Jr (2010) Oil carbon entered the coastal planktonic food web during the Deepwater Horizon oil spill. Environ Res Lett 5:045301

Handley L (2011) Submerged aquatic vegetation. In: Gulf of Mexico Data Atlas. www.ncddc.noaa.gov/website/ DataAtlas/atlas.htm (accessed 15 March 2016)

Hemminga MA, Mateo MA (1996) Stable carbon isotopes in seagrasses: variability in ratios and use in ecological studies. Mar Ecol Prog Ser 140:285-298

* Hertz E, Trudel M, Cox MK, Mazumder A (2015) Effects of fasting and nutritional restriction on the isotopic ratios of nitrogen and carbon: a meta analysis. Ecol Evol 5: 4829-4839

Hobson KA, Barnett-Johnson R, Cerling T (2010) Using isoscapes to track animal migration. In: West J, Bowen G, Dawson $\mathrm{T}$, Tu K (eds) Isoscapes: understanding movement, pattern, and process on Earth through isotope mapping. Springer, Dordrecht, p 273-298

Hohn A, Read A, Fernandez S, Vidal O, Findley L (1996) Life history of the vaquita, Phocoena sinus (Phocoenidae, Cetacea). J Zool 239:235-251

Hohn AA, Rotstein DS, Byrd BL (2013) Unusual mortality events of harbor porpoise strandings in North Carolina, 1997-2009. J Mar Biol 2013:289892

* Hornsby FE, McDonald TL, Balmer BC, Speakman TR and others (2017) Using salinity to identify common bottlenose dolphin habitat in Barataria Bay, Louisiana, USA. Endang Species Res 33:181-192

*Hubard CW, Maze-Foley K, Mullin KD, Schroeder WW (2004) Seasonal abundance and site fidelity of bottlenose dolphins (Tursiops truncatus) in Mississippi Sound. Aquat Mamm 30:299-310

Irwin LJ, Würsig B (2004) A small resident community of bottlenose dolphins, Tursiops truncatus, in Texas: monitoring recommendations. Gulf Mex Sci 22:13-21

Kelly JF (2000) Stable isotopes of carbon and nitrogen in the study of avian and mammalian trophic ecology. Can J Zool 78:1-27

Knoff A, Hohn A, Macko S (2008) Ontogenetic diet changes in bottlenose dolphins (Tursiops truncatus) reflected through stable isotopes. Mar Mamm Sci 24:128-137

Lee SH, Schell DM, McDonald TL, Richardson WJ (2005) Regional and seasonal feeding by bowhead whales Balaena mysticetus as indicated by stable isotope ratios. Mar Ecol Prog Ser 285:271-287

Litz JA, Baran MA, Bowen-Stevens SR, Carmichael RH and others (2014) Review of historical unusual mortality events (UMEs) in the Gulf of Mexico (1990-2009): pro- viding context for the multi-year northern Gulf of Mexico cetacean UME declared in 2010. Dis Aquat Org 112: 161-175

* Lockyer C, Kinze C (2003) Status, ecology and life history of harbour porpoise (Phocoena phocoena), in Danish waters. NAMMCO Sci Publ 5:143-175

Lynn SK, Würsig B (2002) Summer movement patterns of bottlenose dolphins in a Texas bay. Gulf Mex Sci 20: 25-37

MacAvoy SE, Bacalan V, Kazantseva M, Rhodes J, Kim K (2015) Sulfur isotopes show importance of freshwater primary production for Florida manatees. Mar Mamm Sci 31:720-725

Macko S, Ostrom N (1994) Pollution studies using stable isotopes. In: Lajtha K, Michener R (eds) Stable isotopes in ecology and environmental science, Book 7. Blackwell Scientific Publishers, Oxford, p 45-62

Martien KK, Baird RW, Hedrick NM, Gorgone AM and others (2012) Population structure of island-associated dolphins: evidence from mitochondrial and microsatellite markers for common bottlenose dolphins (Tursiops truncatus) around the main Hawaiian Islands. Mar Mamm Sci 28:E208-E232

Mattson MC, Mullin KD, Ingram GW, Hoggard W (2006) Age structure and growth of the bottlenose dolphin (Tursiops truncatus) from strandings in the Mississippi Sound region of the north central Gulf of Mexico from 1986 to 2003. Mar Mamm Sci 22:654-666

* McClelland JW, Valiela I, Michener RH (1997) Nitrogenstable isotope signatures in estuarine food webs: a record of increasing urbanization in coastal watersheds. Limnol Oceanogr 42:930-937

* Michel J, Owens EH, Zengel S, Graham A and others (2013) Extent and degree of shoreline oiling: Deepwater Horizon oil spill, Gulf of Mexico, USA. PLOS ONE 8:e65087

Michener R, Schell D (1994) Stable isotope ratios as tracers in marine aquatic food webs. In: Lajtha $\mathrm{K}$, Michener $\mathrm{R}$ (eds) Stable isotopes in ecology and environmental science, Book 7. Blackwell Scientific Publications, Oxford, p 138-157

Miller C (2003) Abundance trends and environmental habitat usage patterns of bottlenose dolphins (Tursiops truncatus) in lower Barataria and Caminada Bays, Louisiana. $\mathrm{PhD}$ dissertation, Louisiana State University, Baton Rouge, LA

Mirimin L, Miller R, Dillane E, Berrow S, Ingram S, Cross T, Rogan E (2011) Fine-scale population genetic structuring of bottlenose dolphins in Irish coastal waters. Anim Conserv 14:342-353

Möller LM, Wiszniewski J, Allen SJ, Beheregaray LB (2007) Habitat type promotes rapid and extremely localised genetic differentiation in dolphins. Mar Freshw Res 58: 640-648

Moore JE, Merrick RL (2011) Guidelines for assessing marine mammal stocks: report of the GAMMS III Workshop, February 15-18, 2011, La Jolla, California. NOAA Tech Memo NMFS-OPR-47

Natoli A, Birkun A, Aguilar A, Lopez A, Hoelzel AR (2005) Habitat structure and the dispersal of male and female bottlenose dolphins (Tursiops truncatus). Proc R Soc Lond B Biol Sci 272:1217-1226

Newsome SD, Clementz MT, Koch PL (2010) Using stable isotope biogeochemistry to study marine mammal ecology. Mar Mamm Sci 26:509-572

NMFS-OPR (National Marine Fisheries Service - Office of 
Protected Resources) (2016) Marine mammal unusual mortality events. www. nmfs. noaa. gov/pr/health/mmume/ events.html (accessed 11 March 2016)

Ohizumi H, Miyazaki N (2010) Differences in stable isotope ratios of Dall's porpoises (Phocoenoides dalli) between coastal and oceanic areas of the North Pacific. Fish Oceanogr 19:257-261

* Olin JA, Hussey NE, Rush SA, Poulakis GR, Simpfendorfer CA, Heupel MR, Fisk AT (2013) Seasonal variability in stable isotopes of estuarine consumers under different freshwater flow regimes. Mar Ecol Prog Ser 487:55-69

Olsen Z, Fulford R, Dillon K, Graham W (2014) Trophic role of gulf menhaden Brevoortia patronus examined with carbon and nitrogen stable isotope analysis. Mar Ecol Prog Ser 497:215-227

Ostrom NE, Macko SA, Deibel D, Thompson RJ (1997) Seasonal variation in the stable carbon and nitrogen isotope biogeochemistry of a coastal cold ocean environment. Geochim Cosmochim Acta 61:2929-2942

Payo-Payo A, Ruiz B, Cardona L, Borrell A (2013) Effect of tissue decomposition on stable isotope signatures of striped dolphins Stenella coeruleoalba and loggerhead sea turtles Caretta caretta. Aquat Biol 18:141-147

Peltier H, Dabin W, Daniel P, Van Canneyt O, Dorémus G, Huon M, Ridoux V (2012) The significance of stranding data as indicators of cetacean populations at sea: modelling the drift of cetacean carcasses. Ecol Indic 18: 278-290

Peltier H, Baagøe HJ, Camphuysen KC, Czeck R and others (2013) The stranding anomaly as population indicator: the case of harbour porpoise Phocoena phocoena in north-western Europe. PLOS ONE 8:e62180

* Peltier H, Jepson P, Dabin W, Deaville R, Daniel P, Van Canneyt O, Ridoux V (2014) The contribution of stranding data to monitoring and conservation strategies for cetaceans: developing spatially explicit mortality indicators for common dolphins (Delphinus delphis) in the eastern North-Atlantic. Ecol Indic 39:203-214

'Perga M, Gerdeaux D (2005) 'Are fish what they eat' all year round? Oecologia 144:598-606

Peterson BJ, Fry B (1987) Stable isotopes in ecosystem studies. Annu Rev Ecol Syst 18:293-320

* Peterson BJ, Howarth RW, Garritt RH (1986) Sulfur and carbon isotopes as tracers of salt-marsh organic matter flow. Ecology 67:865-874

Pyenson ND (2010) Carcasses on the coastline: measuring the ecological fidelity of the cetacean stranding record in the eastern North Pacific Ocean. Paleobiology 36: $453-480$

Quérouil S, Kiszka J, Cordeiro AR, Cascão I and others (2013) Investigating stock structure and trophic relationships among island-associated dolphins in the oceanic waters of the North Atlantic using fatty acid and stable isotope analyses. Mar Biol 160:1325-1337

Riccialdelli L, Newsome SD, Dellabianca NA, Bastida R, Fogel ML, Goodall RNP (2013) Ontogenetic diet shift in Commerson's dolphin (Cephalorhynchus commersonii commersonii) off Tierra del Fuego. Polar Biol 36:617-627

Richards VP, Greig TW, Fair PA, McCulloch SD and others (2013) Patterns of population structure for inshore bottlenose dolphins along the eastern United States. J Hered 104:765-778

Rosel PE, Hansen L, Hohn A (2009) Restricted dispersal in a continuously distributed marine species: common bottlenose dolphins Tursiops truncatus in coastal waters of the western North Atlantic. Mol Ecol 18:5030-5045

* Rosel PE, Wilcox LA, Sinclair C, Speakman TR, Tumlin MC, Litz JA, Zolman ES (2017) Genetic assignment to stock of stranded common bottlenose dolphins in southeastern Louisiana after the Deepwater Horizon oil spill. Endang Species Res 33:221-234

Rossman S, Barros NB, Ostrom PH, Stricker CA, Hohn AA, Gandhi H, Wells RS (2013) Retrospective analysis of bottlenose dolphin foraging: a legacy of anthropogenic ecosystem disturbance. Mar Mamm Sci 29:705-718

Schlacher TA, Liddell B, Gaston TF, Schlacher-Hoenlinger M (2005) Fish track wastewater pollution to estuaries. Oecologia 144:570-584

Schwacke LH, Smith CR, Townsend FI, Wells RS and others (2014) Health of common bottlenose dolphins (Tursiops truncatus) in Barataria Bay, Louisiana, following the Deepwater Horizon oil spill. Environ Sci Technol 48:93-103

S Schwacke LH, Thomas L, Wells RS, McFee WE and others (2017) Quantifying injury to common bottlenose dolphins from the Deepwater Horizon oil spill using an age-, sexand class-structured population model. Endang Species Res 33:265-279

Fellas AB, Wells RS, Rosel PE (2005) Mitochondrial and nuclear DNA analyses reveal fine scale geographic structure in bottlenose dolphins (Tursiops truncatus) in the Gulf of Mexico. Conserv Genet 6:715-728

Shippee SF (2014) Movements, fishery interactions, and unusual mortalities of bottlenose dolphins. PhD dissertation, University of Central Florida, Orlando, FL

Sinclair C, Sinclair J, Zolman E, Martinez A, Balmer B, Barry K (2015) Remote biopsy sampling field procedures for cetaceans used during the natural resource damage assessment of the MSC252 Deepwater Horizon oil spill. NOAA Tech Memo NMFS-SEFSC-670

* Sulak KJ, Berg JJ, Randall M (2012) Feeding habitats of the Gulf sturgeon, Acipenser oxyrinchus desotoi, in the Suwannee and Yellow rivers, Florida, as identified by multiple stable isotope analyses. Environ Biol Fishes 95: 237-258

Sutton CD (2005) Classification and regression trees, bagging, and boosting. Handb Stat 24:303-329

Therneau TM, Atkinson EJ (2015) An introduction to recursive partitioning using the RPART routines. Mayo Clinic, Rochester, NY

* Thomas L, Booth CG, Rosel PE, Hohn A, Litz J, Schwacke LH (2017) Where were they from? Modelling the source stock of dolphins stranded after the Deepwater Horizon oil spill using genetic and stable isotope data. Endang Species Res 33:253-264

* Trust B, Fry B (1992) Stable sulphur isotopes in plants: a review. Plant Cell Environ 15:1105-1110

Valenzuela LO, Chesson LA, Bowen GJ, Cerling TE, Ehleringer JR (2012) Dietary heterogeneity among western industrialized countries reflected in the stable isotope ratios of human hair. PLOS ONE 7:e34234

Venn-Watson S, Colegrove KM, Litz J, Kinsel M and others (2015a) Adrenal gland and lung lesions in Gulf of Mexico common bottlenose dolphins (Tursiops truncatus) found dead following the Deepwater Horizon oil spill. PLOS ONE 10:e0126538

Venn-Watson S, Garrison L, Litz J, Fougeres E and others (2015b) Demographic clusters identified within the northern Gulf of Mexico common bottlenose dolphin (Tursiops truncatus) unusual mortality event: January 2010-June 2013. PLOS ONE 10:e0117248 
Vizzini S, Mazzola A (2003) Seasonal variations in the stable carbon and nitrogen isotope ratios $\left({ }^{13} \mathrm{C} /{ }^{12} \mathrm{C}\right.$ and $\left.{ }^{15} \mathrm{~N} /{ }^{14} \mathrm{~N}\right)$ of primary producers and consumers in a western Mediterranean coastal lagoon. Mar Biol 142:1009-1018

Vollmer NL, Rosel PE (2013) A review of common bottlenose dolphins (Tursiops truncatus truncatus) in the northern Gulf of Mexico: population biology, potential threats, and management. Southeast Nat 13:1-43

Waring GT, Josephson E, Maze-Foley K, Rosel PE (2015) US Atlantic and Gulf of Mexico Marine Mammal Stock Assessments-2014. NOAA Tech Memo NMFS-NE-231

Wells RS, Scott MD (1990) Estimating bottlenose dolphin population parameters from individual identification and capture-release techniques. Rep Int Whaling Comm 12: 407-415

Wells RS, Rhinehart HL, Hansen LJ, Sweeney JC and others (2004) Bottlenose dolphins as marine ecosystem sentinels: developing a health monitoring system. EcoHealth 1:246-254

Wells RS, Schwacke LH, Rowles TK, Balmer BC and others (2017) Ranging patterns of common bottlenose dolphins Tursiops truncatus in Barataria Bay, Louisiana, following the Deepwater Horizon oil spill. Endang Species Res 33: 159-180

Wilkin SM, Cordaro J, Gulland FM, Wheeler E and others (2012) An unusual mortality event of harbor porpoises (Phocoena phocoena) off central California: increase in blunt trauma rather than an epizootic. Aquat Mamm 38: 301-310

Editorial responsibility: Jeffrey Seminoff, La Jolla, California, USA
Wilson RM, Kucklick JR, Balmer BC, Wells RS, Chanton JP, Nowacek DP (2012) Spatial distribution of bottlenose dolphins (Tursiops truncatus) inferred from stable isotopes and priority organic pollutants. Sci Total Environ 425:223-230

Wilson R, Nelson J, Balmer B, Nowacek D, Chanton J (2013) Stable isotope variation in the northern Gulf of Mexico constrains bottlenose dolphin (Tursiops truncatus) foraging ranges. Mar Biol 160:2967-2980

*Wissel B, Fry B (2005) Tracing Mississippi River influences in estuarine food webs of coastal Louisiana. Oecologia 144:659-672

Witteveen BH, Worthy GAJ, Wynne KM, Roth JD (2009) Population structure of North Pacific humpback whales on their feeding grounds revealed by stable carbon and nitrogen isotope ratios. Mar Ecol Prog Ser 379: 299-310

Worthy G, Wells R, Martin S, Shippee S (2013) Impacts of the 2010 Deepwater Horizon oil spill on estuarine bottlenose dolphin populations in the west Florida panhandle. Final Technical Report, Contract No 4710-1101- 00-D. Florida Institute of Technology, Melbourne, FL

* Yang WC, Chou LS, Jepson PD, Brownell RL Jr and others (2008) Unusual cetacean mortality event in Taiwan, possibly linked to naval activities. Vet Rec 162:184-186

Yarbro L, Carlson PR Jr (2013) Seagrass integrated mapping and monitoring program: mapping and monitoring report No. 1. Tech Rep TR-17:127. Fish and Wildlife Research Institute, St. Petersburg, FL

Submitted: June 6, 2016; Accepted: October 27, 2016 Proofs received from author(s): January 13, 2017 